\title{
PENGGUNAAN UMPAN CACING WAK-WAK (Xenosiphon sp.) PADA PANCING ULUR YANG DIOPERASIKAN SIANG HARI DI KECAMATAN MANGGAR PULAU BELITUNG
}

\author{
Deta Oryzae Saputra ${ }^{1 *}$, Zulkarnain ${ }^{1}$, Fis Purwangka ${ }^{1}$, dan Izza Mahdiana Apriliani ${ }^{2}$ \\ ${ }^{1}$ Departemen Pemanfaatan Sumberdaya Perikanan, Fakultas Perikanan dan Ilmu Kelautan, \\ Institut Pertanian Bogor \\ ${ }^{2}$ Fakultas Perikanan dan Ilmu Kelautan, Universitas Padjadjaran \\ E-mail korespondensi: zulkarnaian_psp@yahoo.com
}

\begin{abstract}
Abstrak
Penelitian ini bertujuan untuk mengetahui komposisi hasil tangkapan ikan, menganalisis pengaruh umpan wak-wak yang dioperasikan siang hari dengan umpan yang biasa nelayan gunakan di Kecamatan Manggar dan menganalisis pengaruh perbedaan waktu penangkapan perjenis ikan dominan. Penelitian ini menggunakan metode uji coba penangkapan (experimental fishing) dengan 20 kali ulangan. Komposisi hasil tangkapan terdiri atas 11 jenis ikan dengan jumlah total 272 ekor yang didominasi oleh ikan kuwe kuning (Caranx bartholomei) sebanyak 68 ekor atau 25\%, kunyit (Lutjanus vita) sebanyak 39 ekor atau 14,3\%, kurisi (Nemipterus hexodon) sebanyak 36 ekor atau 13,2\% dan timun (Lutjanus carponotatus) sebanyak 31 ekor atau 11,4\%. Perbandingan hasil tangkapan pancing ulur berbeda pada setiap perlakuan. Pancing ulur dengan menggunakan umpan wak-wak memberikan jumlah hasil tangkapan sebanyak 107 ekor atau 39,34\%, umpan cumicumi sebanyak 83 ekor atau 30,51\% dan umpan ikan juwi sebanyak 82 ekor atau 30,15\%. Jenis umpan memberikan pengaruh nyata terhadap jumlah total hasil tangkapan dengan selang kepercayaan $95 \%$.
\end{abstract}

Kata kunci: wak-wak, komposisi hasil tangkapan, pancing ulur, umpan.

USE OF SIPUNCULA BAIT (Xenosiphon sp.) IN THE HAND LINES OPERATED DAY IN MANGGAR DISTRICT, BELITUNG ISLAND

\begin{abstract}
The research was designed in order to determine the composition of total fish catch, to analyze the influence of sipuncula bait operated compared to regular bait which usually used by fisherman at Manggar Districts and to analyze the effect of different fishing time of each dominant fish species. The research was performed by experimental fishing methods by the number of replication of 20 repeat. Catch composition were consisted of 11 species with total catches 272 individuals, dominated by yellow jack (Caranx bartholomei) with 68 individuals or 25\%, brownstripe snapper (Lutjanus vita) with 39 individuals or 14,3\%, threadfin brean (Nemipterus hexodon) with 36 individuals or 13,2\% and Spanish Flag Snapper (Lutjanus carponotatus) with 31 individuals or $11,4 \%$. Proportion of hand line catches using three different types of bait were different. Handline with sipuncula as bait caught 107 individuals or 39,34\%, with squids as bait caught 83 individuals or $30,51 \%$ and better than handline with sardines bait which caught 82 individuals or $30,15 \%$ of total catch. Bait types showed significance effect on total catch with confidence interval of $95 \%$.
\end{abstract}

Keywords: bait, catch composition, sipuncula, handline, daytime

\section{PENDAHULUAN}

Kabupaten Belitung merupakan bagian dari wilayah Provinsi Kepulauan Bangka Belitung yang juga merupakan wilayah kepulauan yang terdiri dari 98 buah pulau besar dan kecil.Sebagian besar penduduknya, terutama yang tinggal di kawasan pesisir pantai, sangat akrab dengan kehidupan bahari yang kaya dengan hasil ikan laut. Berbagai olahan makanan yang berbahan ikan menjadi makanan sehari-hari penduduknya. Kekayaan laut menjadi salah satu sumber mata pencaharian penduduk Belitung.

Salah satu alat tangkap yang dominan digunakan di Kabupaten Belitung khususnya Kecamatan Manggar adalah pancing ulur (hand line) diantara alat tangkap dominan lainnya seperti bubu dan jaring insang. Menurut data statistik DKP Beltim (2013) jumlah unit alat tangkap bubu sebesar 1447 unit, jaring insang 2426 unit dan pancing ulur sebesar 2449 unit. Hal ini dikarenakan pancing ulur adalah salah satu alat tangkap yang umum dikenal oleh masyarakat luas, utamanya dikalangan nelayan.
Pancing merupakan alat penangkapan ikan yang sederhana dan biasanya dioperasikan oleh nelayan untuk memenuhi kebutuhan hidupnya. Hasil tangkapan ikan pancing ulur pada umumnya memiliki ukuran dan jenis tidak seragam yaitu terdiri dari sumberdaya ikan permukaan dan ikan dasar. Jenis hasil tangkapan tersebut disesuaikan berdasarkan tujuan pengoperasian dan target penangkapan. Ikan yang menjadi target utama penangkapan pada pancing ulur biasanya ikan-ikan yang memiliki nilai ekonomis tinggi, seperti ikanikan perairan dasar termasuk ikan karang. Jenis ikan dasar yang tertangkap pancing ulur adalah Layur (Trichiurus sp.), Bawal (Pampus sp.), Kakap (Lutjanus sp.), Kerapu (Epinephelus sp.) dan lain sebagainya (Muammar 2013).

Faktor yang sangat berpengaruh penting dalam operasi penangkapan ikan menggunakan pancing ulur adalah umpan. Umpan merupakan salah satu alat bantu yang berpengaruh pada daya tarik dan rangsangan ikan (Gunarso 1985). Umpan merupakan salah satu bentuk rangsangan yang berbentuk fisika/kimiawi yang dapat memberikan respon 
terhadap ikan-ikan tertentu dalam tujuan penangkapan ikan (Ruivo 1982 dalam Hendrotomo 1989). Adapun umpan yang sering digunakan oleh nelayan pulau Belitung, khususnya kecamatan manggar untuk mengoperasikan alat tangkap pancing ulur tersebut antara lain umpan segar yaitu ikan Juwi (Sardinella gibosa), Cumi-cumi (Loligo sp.) dan beberapa umpan hidup seperti ikan Selar (Selaroides leptolepis) dan ikan Tamban (Spratelloides sp.).

Wak-wak atau sipuncula (Xenosiphon sp.) merupakan hewan laut mirip cacing tapi tanpa segmen. Sipuncula biasanya disebut sebagai cacing laut atau cacing kacang (Peanut Worm), tubuhnya terbagi menjadi badan utama (trunk) dan belalai (introvert) yang bisa ditarik ke dalam atau belakang, perbandingan panjang kedua bagian itu bervariasi untuk tiap-tiap jenis (Cutler 1994). Sipuncula merupakan filum minor dalam kelompok besar hewan bilateria, yaitu kelompok hewan yang bersifat tripoblastik, tubuhnya simetris bilateral dan terbentuk dari tiga macam lapisan benih (endodermis, mesodermis dan ektodermis). Filum ini secara khusus belum dipelajari dengan baik, dilaporkan baru sekitar 300 jenis yang telah dideskripsi secara formal, semua di laut dan umumnya perairan dangkal (Kozloff 1990). Menurut Silahooy (2008) bahwa kandungan gizi dan nutrisi pada wak-wak atrau sipuncula sangat tinggi sehingga fungsinya sangat luas untuk dimanfaatkan.

Tingkah laku ikan terhadap umpan memiliki sifat yang berbeda beda. Ikan memiliki naluri untuk mencari makan dengan menggunakan organ sensori yang dimiliki, organ penciuman dan line lateralis (Liang et al. 1998 dan Baker et al. 2002). Bau yang diterima organ penciuman akan mengkondisikan rheotaxis ikan untuk melakukan respons dengan cepat dan efisien terhadap sumber bau (makanan) tanpa melakukan penyeleksian terhadap informasi bau tersebut sebagai suatu isyarat yang kompleks (Carton dan Montgomery 2003).

Wak-wak atau sipuncula dapat diidentifikasi menjadi umpan alternatif dalam penangkapan ikan dasar di laut, karena memiliki kandungan protein yang cukup tinggi mencapai 16-17\%. Menurut Silahooy (2008) bahwa wak-wak atau Sipuncula di Pulau Saparua Maluku Tengah mengandung 3 asam lemak esensial yaitu linoleat, linolenat dan arakidonat dan asam lemak non esensial yaitu asam miristat, palmitat, pentadekanoat dan asam steara. Kandungan protein dan asam lemak tersebut dapat diidentifikasi sebagai perangsang nafsu makan ikan. Oleh karena itu, diperlukan penelitian tentang umpan pada pancing ulur yang dioperasikan pada siang hari di Kecamatan Manggar Pulau Belitung karena nelayan pancing ulur biasanya mengoperasikan unit pancing ulur pada siang hari

\section{METODE PENELITIAN}

Pengambilan data ini akan dilaksanakan pada bulan Januari - maret 2016 yang bertempat di Kecamatan Manggar, Kabupaten Belitung Timur, Provinsi Bangka Belitung (Gambar 1).

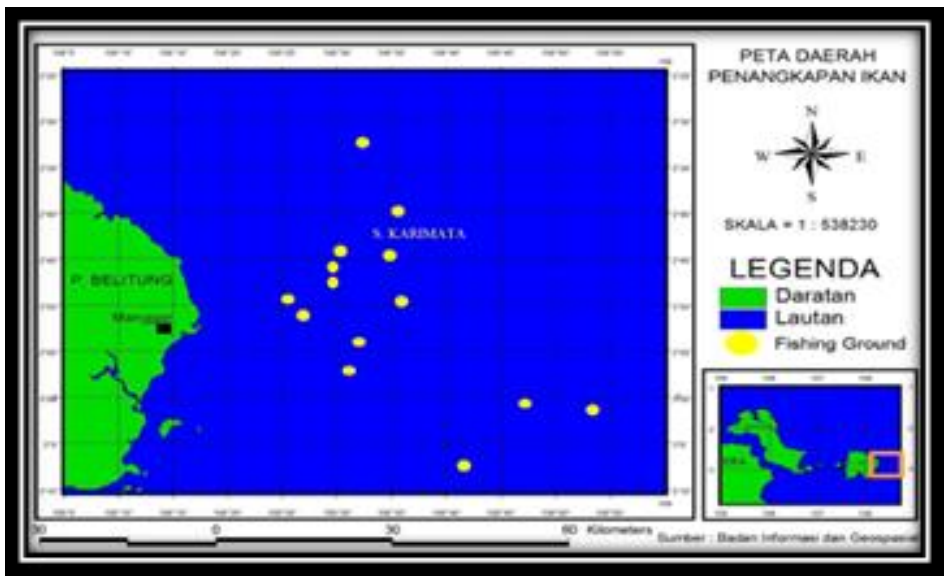

Gambar 1 Peta Lokasi Penelitian dan Daerah Penangkapan Ikan

Penelitian ini merupakan uji coba penangkapan ikan (experimental fishing) dengan melakukan kegiatan operasi penangkapan ikan secara langsung di lapangan. Penelitian ini membandingkan hasil tangkapan alat tangkap pancing ulur (hand line) dengan diberi perlakuan berupa pemberian umpan standar yang biasa digunakan oleh nelayan misalnya ikan juwi (Sardinella gibosa) dan cumi-cumi (Loligo sp.) yang dibandingkan dengan umpan wak-wak
(Xenosiphon sp.). unti pancing yang digunakan berjumlah tiga unit dengan satu unit memiliki jumlah satu mata pancing. Setelah itu tiga umpan yang berbeda tersebut dikaitkan di setiap mata pancing tersebut. Sebelum ketiga umpan dikaitkan ke mata pancing, terlebih dahulu umpan juwi disayat, umpan cumi-cumi di potong dan dipukul-pukul dengan kayu dan umpan wak-wak dipotong dan disayat. Penelitian ini dilakukan sebanyak 20 kali ulangan (7 trip). 


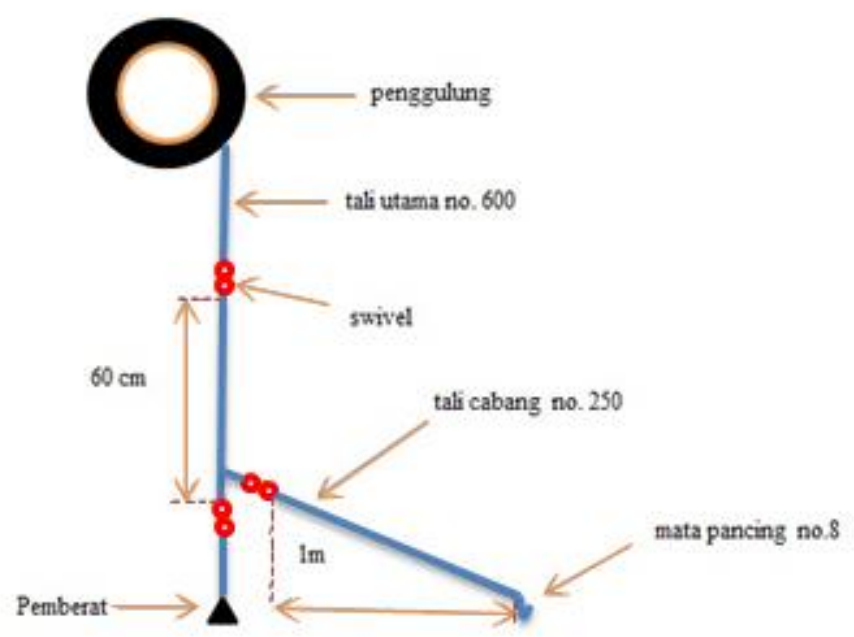

Gambar 2 Konstruksi alat tangkap pancing ulur

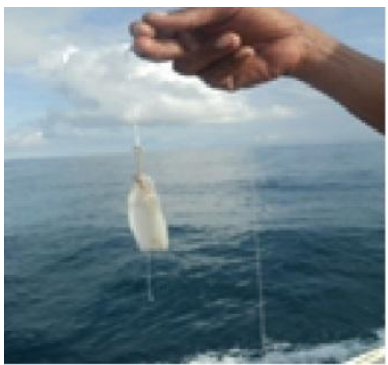

(a)



(b)

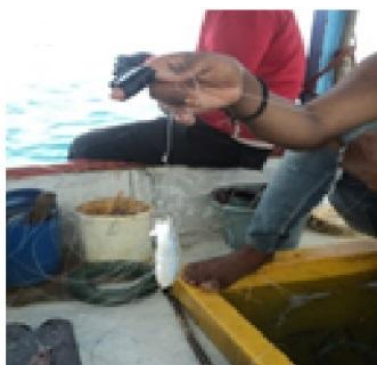

(c)

Gambar 3 Pemasangan umpan cumi-cumi hasil dipotong (a), umpan wak-wak dipotong dan disayat (b) dan umpan juwi disayat (c)

Analisis yang dilakukan pada penelitian ini ada dua macam analisis, yaitu (1) Analisis deskriptif berupa data hasil tangkapan disajikan dalam bentuk tabel beserta diagram, kemudian dianalisis secara deskriptif menurut pokok-pokok pembahasan seperti komposisi total hasil tangkapan pancing ulur, hasil tangkapan pancing ulur pada umpan yang berbeda dan jenis ikan dominan hasil tangkapan pada umpan yang berbeda dari 20 kali ulangan penangkapan. Selanjutnya (2) Uji Statistik dengan data yang diperoleh terlebih dahulu diuji menggunakan uji normalitas. Uji normalitas bertujuan untuk melihat kenormalan distribusi nilai. Metode yang digunakan adalah kolmogorov-sminov. Jika nilai signifikansi uji normalitas > 0,05 maka dapat dikatakan data berdistribusi normal dan jika nilai signifikansi uji normalitas $\leq 0,05$ maka dapat dikatakan data berdistribusi tidak normal (Santoso 2001). Setelah data menyebar normal, selanjutnya peneliti menggunakan rancangan percobaan yaitu Rancangan acak lengkap. Rancangan acak lengkap atau completely randomized design merupakan salah satu model rancangan dalam rancangan percobaan. Rancangan acak lengkap ini digunakan bila unit percobaan homogen. Rancangan ini disebut rancangan acak lengkap, karena pengacakan perlakauan dilakukan pada seluruh unit percobaan. Rancangan ini dapat digunakan untuk melakukan percobaan di laboratorium atau di rumah kaca atau lapangan.

Selanjutnya dilakukan Uji-F untuk mengetahui perbedaan komposisi jumlah hasil tangkapan dari ketiga jenis umpan tersebut yaitu umpan ikan juwi, cumi-cumi dan umpan alternatif cacing wak-wak (Xenosiphon sp.) pada penangkapan pancing ulur. Analisis ragam digunakan untuk menguji hipotesisi yang dilambangkan dengan $\mathrm{F}$, dilakukan Uji-T untuk mengetahui berapa besar pengaruh ketiga jenis umpan pada pancing ulur. Model linier yang tepat untuk rancangan acak lengkap menurut (Walpole 1995) :

$$
Y i j(t)=\mu+P(t)+\varepsilon(t)
$$

Dimana :

i $\quad=1,2, \ldots \mathrm{n} ;$ dan $\mathrm{t}=1,2, \ldots \mathrm{n}$

$\boldsymbol{Y} \boldsymbol{i j}(\boldsymbol{t})=$ Nilai pengamatan pada baris ke-i, kolom ke-j yang mendapat perlakuan ke-t.

$\boldsymbol{\mu} \quad=$ Nilai rata-rata umum

$\boldsymbol{P}(\boldsymbol{t}) \quad=$ Pengaruh perlakuan ke-t

$\varepsilon(t) \quad=$ Pengaruh galat yang memperoleh perlakuan ke-t 
Hipotesis yang digunakan dalam rancangan acak lengkap ini adalah :

- $\quad H_{0}: \propto_{i}=0$, berarti tidak ada perbedaan hasil tangkapan terhadap pancing ulur dengan umpan yang berbeda.

- $H_{0}: \propto_{i} \neq 0$, berarti ada perbedaan hasil tangkapan terhadap pancing ulur dengan umpan yang berbeda.

Adapun dasar pengambilan keputusan melalui uji-F yaitu :

1. Jika $\mathrm{F}$ hitung $>\mathrm{F}$ tabel maka tolak $\mathrm{H} 0$, berarti ada perbedaan hasil tangkapan terhadap umpan yang berbeda

2. Jika $\mathrm{F}$ hitung $<\mathrm{F}$ tabel maka gagal tolak H0, berarti tidak ada perbedaan hasil tangkapan terhadap umpan yang berbeda

3. Apabila Uji-F didapat hasil $\mathrm{F}$ hitung $>\mathrm{F}$ tabel selanjutnya dapat dilakukan Uji-t

Dasar pengambilan keputusan yang akan diambil dalam Uji-t adalah

a. Jika t hitung $>\mathrm{t}$ tabel maka tolak $H O$, berarti perlakuan ketiga jenis umpan yang berpasangan (umpan cumi-cumi dengan wak-wak, umpan cumi-cumi dengan juwi dan umpan ikan juwi dengan wak-wak) memberikan pengaruh nyata terhadap hasil tangkapan.

b. Jika t hitung $<\mathrm{t}$ tabel maka gagal tolak $\mathrm{HO}$, berarti perlakuan ketiga jenis umpan yang (umpan cumi-cumi dengan wak-wak, umpan cumi-cumi dengan juwi dan umpan ikan juwi dengan wak-wak) tidak memberikan pengaruh nyata terhadap hasil tangkapan.

Atau

a. Jika $\mathrm{p}$ (peluang menolak Ho) $<\alpha(0.05)$ maka tolak H0, berarti perlakuan berbeda penangkapan pancing ulur dengan jenis umpan yang berbeda memberikan pengaruh nyata terhadap hasil tangkapan

b. Jika $\mathrm{p}$ (peluang menolak Ho) $>\alpha(0.05)$ maka tolak $\mathrm{H} 0$, berarti perlakuan berbeda penangkapan pancing ulur dengan jenis umpan yang berbeda tidak memberikan pengaruh nyata terhadap hasil tangkapan.

\section{HASIL DAN PEMBAHASAN}

\section{Komposisi Total Hasil Tangkapan Pancing Ulur ( Hand Line)}

Hasil tangkapan pancing ulur yang dioperasikan sebanyak 20 kali ulangan terdiri dari 11 jenis ikan hasil tangkapan, terdiri dari ikan kuwe kuning (Caranx bartholomei), kuwe rambe (Alectis ciliaris), Barakuda (Sphyraena baraccuda), Kunyit (Lutjanus vita), timun (Lutjanus carponotatus), lencam (Lethrinus lentjan), kurisi (Nemipterus hexodon), kerapu sunu (Plectropomus areolatus), kerapu ekor gelap (Epinephelus bleekeri), ungar (Lutjanus johnii), dan kakap merah (Lutjanus campechanus). Total hasil tangkapan per individu ikan berjumlah 272 ekor dengan bobot total hasil tangkapan sebesar 216,1 kg. Komposisi hasil tangkapan pancing ulur bisa dijelaskan pada Tabel 1 .

Tabel 1 Komposisi hasil tangkapan pancing ulur (Hand line)

\begin{tabular}{llllcccc}
\hline \multirow{2}{*}{ No } & \multicolumn{2}{c}{ Jenis Ikan } & Jumlah & \multicolumn{2}{c}{ Berat } \\
\cline { 2 - 8 } & $\begin{array}{l}\text { Nama } \\
\text { Lokal }\end{array}$ & Nama & Namum & Ekor & $\%$ & Kg & $\%$ \\
\hline 1 & Bulat & Kuwe kuning & Caranx bartholomei & 68 & 25,0 & 117,2 & 54,2 \\
2 & Tupak & Kuwe rambe & Alectis ciliaris & 18 & 6,6 & 27,6 & 12,8 \\
3 & Kocol & Barakuda & Sphyraena baraccuda & 29 & 10,7 & 12,5 & 5,8 \\
4 & Kuning & Kunyit & Lutjanus vita & 39 & 14,3 & 8,85 & 4,1 \\
5 & Bujor timun & Timun & Lutjanus carponotatus & 31 & 11,4 & 7,55 & 3,5 \\
6 & Ketambak & Lencam & Lethrinus lentjan & 19 & 7,0 & 15,25 & 7,1 \\
7 & Kerisi & Kurisi & Nemipterus hexodon & 36 & 13,2 & 6 & 2,8 \\
8 & Kerapu sunok & Kerapu sunu & Plectropomus areolatus & 7 & 2,6 & 2,2 & 1,0 \\
9 & Kerapu sawar & Kerapu ekor gelap & Epinephelus bleekeri & 12 & 4,4 & 4,05 & 1,9 \\
10 & Senggarat & Ungar & Lutjanus johnii & 6 & 2,2 & 5,1 & 2,4 \\
11 & kakap merah & Kakap merah & Lutjanus campechanus & 7 & 2,6 & 9,8 & 4,5 \\
\hline & Total & & & $\mathbf{2 7 2}$ & $\mathbf{1 0 0}$ & $\mathbf{2 1 6 , 1}$ & $\mathbf{1 0 0}$ \\
\hline
\end{tabular}

\section{Komposisi Hasil Tangkapan Berdasarkan Jenis Umpan}

Tangkapan pancing ulur memilki hasil yang berbeda-beda pada setiap umpan yang digunakan yaitu umpan cumi-cumi, umpan juwi dan umpan wak-wak. Jumlah hasil tangkapan pada setiap umpan disajikan pada grafik Gambar 4 dan 5 . 




Gambar 4 Total hasil tangkapan dalam (ekor) berdasarkan penggunaan jenis umpan



Gambar 5 Total hasil tangkapan dalam $(\mathrm{kg})$ berdasarkan penggunaan jenis umpan

\section{Hasil Analisis Statistik Uji-t}

Uji $t$ yang dilakukan adalah membandingkan dua umpan dari tiga jenis umpan tersebut yaitu cumi-cumi dengan ikan juwi, cumicumi dengan wak-wak dan ikan juwi dengan wakwak. Berdasarkan analisis uji t statistik pengaruh kedua jenis umpan (cumi-cumi dan juwi) terhadap hasil tangkapan (ekor) diperoleh nilai Sig.(2-tailed) > $\alpha 0,05(0,930>0,05)$, kedua jenis umpan (cumi-cumi dengan wak-wak) diperoleh nilai Sig.(2-tailed) $<\alpha$ $0,05(0,037<0,05)$ dan kedua jenis umpan (ikan juwi dan wak-wak) diperoleh nilai Sig.(2-tailed) $<\alpha$ $0,05(0,019<0,05$. Hal ini menunjukkan bahwa perlakuan dari kedua jenis umpan (cumi-cumi dengan ikan juwi) tidak memberikan pengaruh nyata terhadap jumlah total hasil tangkapan (ekor), sedangkan kedua jenis umpan (cumi-cumi dengan wak-wak dan ikan juwi dengan wak-wak) memberikan pengaruh nyata terhadap jumlah total hasil tangkapan (ekor). Untuk analisis uji t statistik pengaruh perbedaan kedua jenis umpan (cumi-cumi dengan juwi) terhadap hasil tangkapan $(\mathrm{kg})$ diperoleh nilai Sig.(2-tailed) $<\alpha 0,05(0,010<0,05)$, kedua jenis umpan (cumi-cumi dengan wak-wak) diperoleh nilai Sig.(2-tailed) $>\alpha 0,05(0,174>0,05)$ dan kedua jenis umpan (ikan juwi dengan wak-wak) diperoleh nilai Sig.(2-tailed) $<\alpha 0,05(0,048<0,05$. Hal ini menunjukkan kedua jenis umpan (cumi-cumi dengan wak-wak) tidak memberikan pengaruh nyata terhadap jumlah total hasil tangkapan (berat) sedangkan kedua jenis umpan (cumi-cumi dengan ikan juwi dan ikan juwi dengan wak-wak) memberikan pengaruh nyata terhadap jumlah total hasil tangkapan (berat) pada selang kepercayaan $95 \%$.

\section{Hasil Tangkapan Ikan Dominan pada Umpan yang Berbeda}

Berdasarkan hasil tangkapan pada alat tangkap pancing ulur menggunakan tiga jenis umpan yang berbeda, diperoleh hasil tangkapan 4 jenis ikan dominan yaitu ikan kuwe kuning (Caranx bartholomei), ikan kunyit (Lutjanus vita), ikan kurisi (Nemipterus hexodon) dan ikan timun (Lutjanus carponotatus). Nilai rata-rata hasil tangkapan (ekor) per ulangan \pm SE pada umpan cumi-cumi adalah 4,15 
ekor $\pm 0,274$, pada umpan ikan juwi adalah 4,1 ekor $\pm 0,376$ dan pada umpan wak-wak adalah 5,35 ekor \pm 0,406 . Ikan kuwe kuning yang menggunakan umpan cumi-cumi memperoleh hasil tangkapan sebanyak 12 ekor, pada umpan ikan juwi sebanyak 42 ekor dan pada umpan wak-wak sebanyak 14 ekor. Nilai ratarata hasil tangkapan adalah 0,6 ekor $\pm 0,169$ pada umpan cumi-cumi, 2,1 ekor $\pm 0,228$ pada umpan ikan juwi dan 0,7 ekor $\pm 0,206$ pada umpan wak-wak. Ikan kunyit yang menggunakan umpan cumi-cumi memperoleh hasil tangkapan sebanyak 19 ekor, pada umpan ikan juwi sebanyak 2 ekor dan pada umpan wak-wak sebanyak 18 ekor. Nilai rata-rata hasil tangkapan adalah 0,95 ekor $\pm 0,198$ pada umpan cumi-cumi 0,1 ekor $\pm 0,069$ pada umpan ikan juwi dan 0,9 ekor $\pm 0,228$ pada umpan wak-wak. Ikan kurisi yang menggunakan umpan cumi-cumi memperoleh hasil tangkapan sebanyak 16 ekor, pada umpan ikan juwi sebanyak 2 ekor dan pada umpan wak-wak sebanyak 18 ekor. Nilai rata-rata hasil tangkapan adalah 0,6 ekor $\pm 0,152$ pada umpan cumi-cumi 0,1 ekor $\pm 0,069$ pada umpan ikan juwi dan 0,85 ekor $\pm 0,196$ pada umpan wak-wak. Ikan timun yang menggunakan umpan cumi-cumi memperoleh hasil tangkapan sebanyak 12 ekor, pada umpan ikan juwi sebanyak 2 ekor dan pada umpan wak-wak sebanyak 17 ekor. Nilai rata-rata hasil tangkapan adalah 0,8 ekor $\pm 0,172$ pada umpan cumi-cumi 0,1 ekor $\pm 0,069$ pada umpan ikan juwi dan 0,9 ekor $\pm 0,204$ pada umpan wak-wak.

\section{Ikan kuwe kuning (Caranx bartholomei)}

Ikan kuwe kuning memperoleh rata-rata hasil tangkapan terbanyak dengan menggunakan umpan ikan juwi. Nilai rata-rata $\pm \mathrm{SE}$ adalah 2,1 $\pm 0,228$ sedangkan menggunakan umpan wakwak dan cumi cumi berturut-turut nilai rata-rata $\pm \mathrm{SE}$ adalah $0,7 \pm 0,206$ dan $0,6 \pm 0,169$ (Gambar 6)

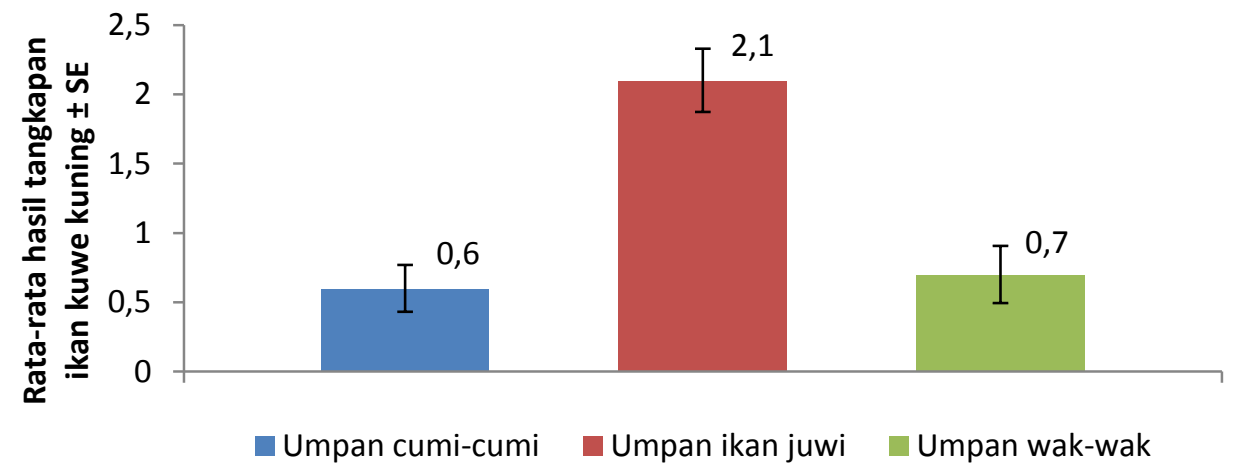

Jenis umpan

Gambar 6 Rata-rata tangkapan kuwe kuning (Caranx bartholomei) berdasarkan jenis umpan

\section{Ikan kunyit (Lutjanus vita)}

Ikan kunyit memperoleh rata-rata hasil tangkapan terbanyak dengan menggunakan umpan cumi-cumi. Nilai rata-rata \pm SE adalah $0,95 \pm 0,198$ sedangkan menggunakan umpan wak-wak dan ikan juwi berturut-turut nilai ratarata \pm SE adalah $0,9 \pm 0,228$ dan $0,1 \pm 0,69$ (Gambar 7).

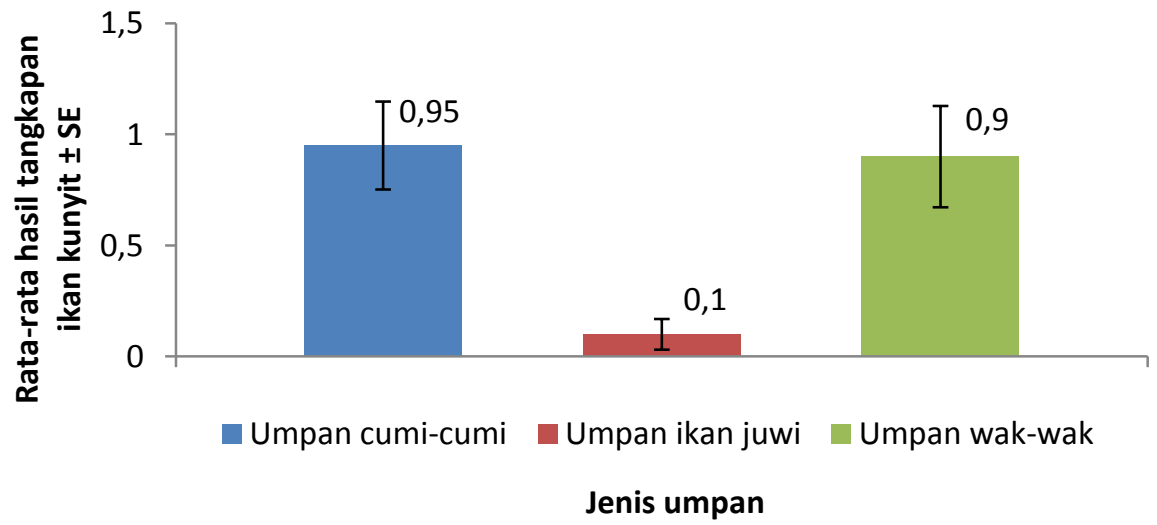

Gambar 7 Rata-rata hasil tangkapan ikan kunyit (Lutjanus vita) berdasarkan jenis umpan

\section{Ikan kurisi (Nemipterus hexodon)}

Ikan kurisi memperoleh rata-rata hasil tangkapan terbanyak dengan menggunakan umpan wakwak. Nilai rata-rata \pm SE adalah $0,85 \pm 0,196$ (Gambar 8). sedangkan menggunakan umpan cumi-cumi dan ikan juwi berturut-turut nilai rata-rata $\pm \mathrm{SE}$ adalah $0,6 \pm 0,152$ dan $0,1 \pm 0,69$ 


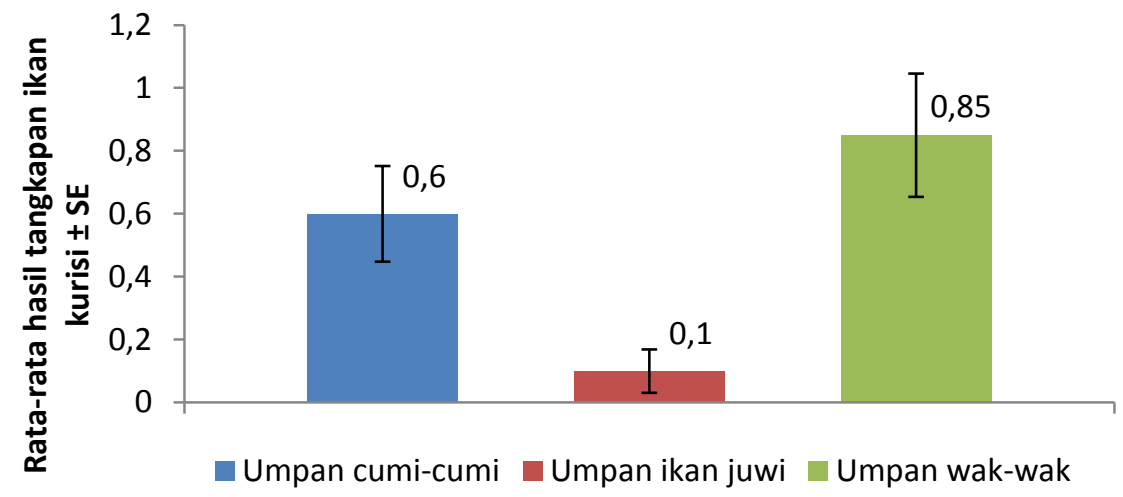

Gambar 8 Rata-rata hasil tangkapan ikan kurisi (Nemipterus hexodon) berdasarkan jenis umpan

\section{Ikan timun (lutjanus carponotatus )}

Ikan timun memperoleh rata-rata hasil tangkapan terbanyak dengan menggunakan umpan wak-

\section{Jenis umpan}

wak. Nilai rata-rata \pm SE adalah $0,9 \pm 0,204$ sedangkan menggunakan umpan cumi-cumi dan ikan juwi berturut-turut nilai rata-rata $\pm \mathrm{SE}$ adalah 0,8 $\pm 0,172$ dan 0,1 $\pm 0,69$ (Gambar 9).

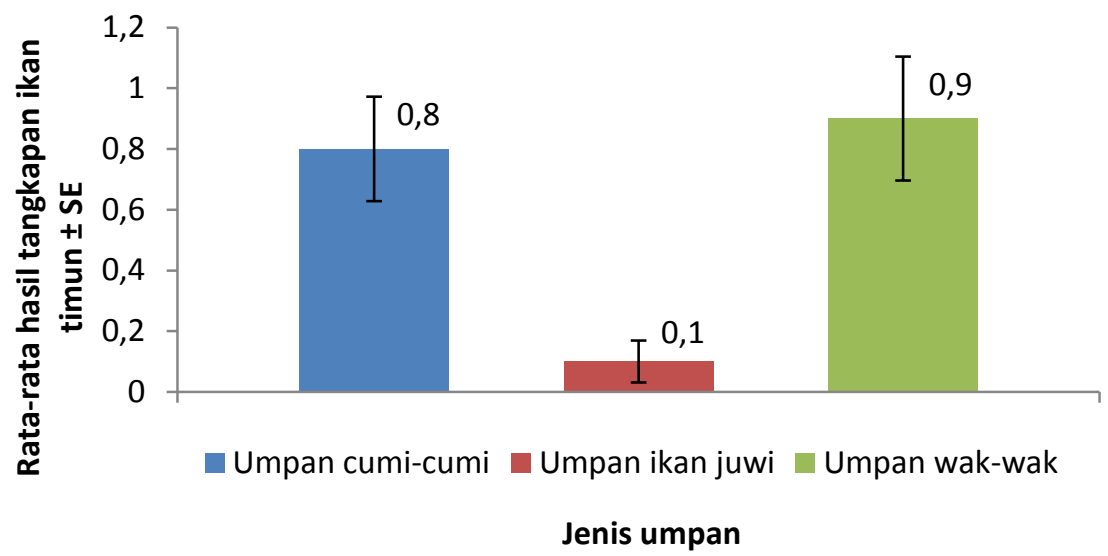

Gambar 9 Rata-rata tangkapan ikan timun (Lutjanus carponotatus) berdasarkan jenis umpan

\section{Periode waktu penangkapan ikan}

1. Periode waktu tertangkap ikan kuwe kuning Ikan kuwe kuning memperoleh hasil tangkapan terbanyak pada pukul $06.00-12.00$ WIB dengan jumlah 31 ekor dan nilai rata-rata \pm SE 1,55 ekor $\pm 0,276$ pada umpan ikan juwi. Umpan cumicumi memiliki tangkapan sama banyak pada pukul 06.00-12.00 dan 12.00-18.00 dengan jumlah 6 ekor dan nilai rata-rata \pm SE 0,3 ekor \pm 0,128 dan umpan wak-wak memiliki tangkapan terbanyak pada pukul 06.00-12.00 WIB dengan jumlah 8 ekor dan nilai rata-rata \pm SE 0,4 ekor \pm 0,169 (Gambar 10).



- Umpan cumi-cumi

- Umpan ikan juwi

- Umpan wak-wak

Gambar 10 Periode rata-rata hasil tangkapan ikan kuwe kuning (Caranx bartholomei) 


\section{Periode waktu tertangkap ikan kunyit}

Ikan kunyit memperoleh hasil tangkapan terbanyak pada pukul 06.00-12.00 WIB dengan jumlah 11 ekor dan nilai rata-rata \pm SE 0,5 ekor $\pm 0,154$ pada umpan cumi-cumi. Umpan ikan juwi memiliki tangkapan sama banyak pada pukul 06.00-12.00 dan 12.00-18.00 WIB dengan jumlah 1 ekor dan nilai rata-rata \pm SE 0,05 ekor $\pm 0,05$ dan umpan wak-wak memiliki tangkapan terbanyak pada pukul 06.00-12.00 WIB dengan jumlah 10 ekor dan nilai rata-rata \pm SE 0,55 ekor $\pm 0,17$ (Gambar 11).

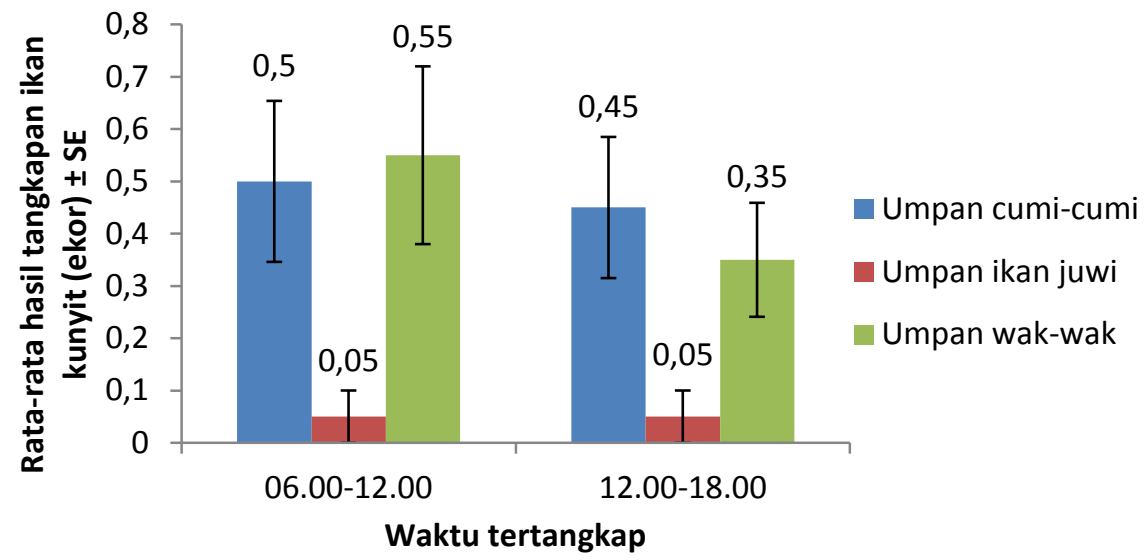

Gambar 11 Periode rata-rata tertangkapnya ikan kunyit (Lutjanus vita)

\section{Periode waktu tertangkap ikan kurisi}

Ikan kurisi memperoleh hasil tangkapan terbanyak pada pukul 06.00-12.00 WIB dengan jumlah 9 ekor dan nilai rata-rata \pm SE 0,35 ekor $\pm 0,109$ pada umpan cumi-cumi. Umpan ikan juwi memiliki tangkapan sama banyak pada pukul 06.00-12.00 dan 12.00-18.00 WIB dengan jumlah 1 ekor dan nilai rata-rata \pm SE 0,05 ekor \pm 0,05 dan umpan wak-wak memiliki tangkapan terbanyak pada pukul 06.00-12.00 WIB dengan jumlah 10 ekor dan nilai rata-rata \pm SE 0,55 ekor $\pm 0,135$ (Gambar 12).

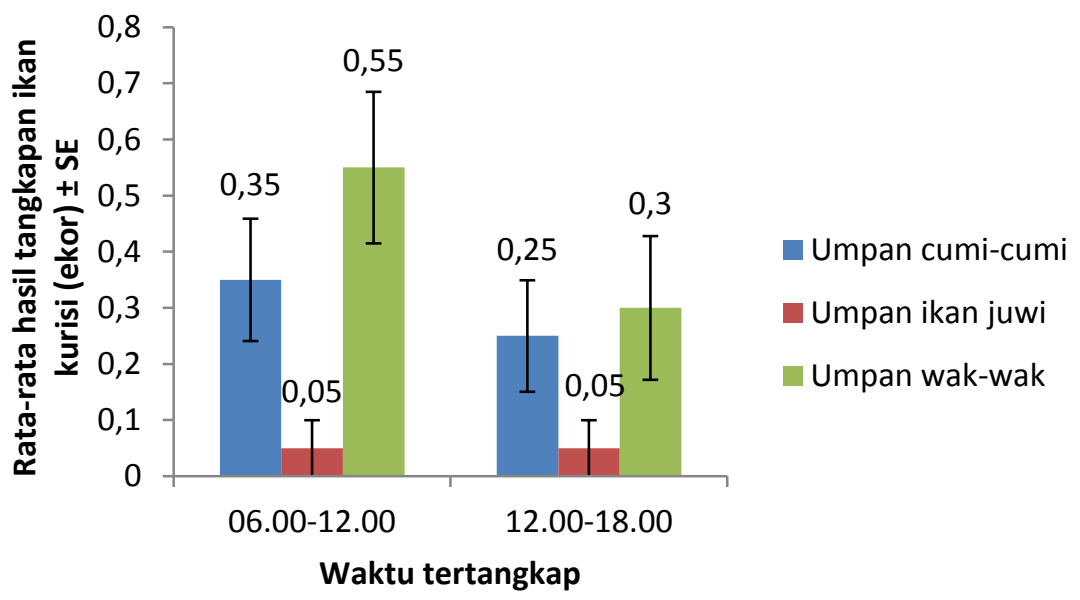

Gambar 12 Periode rata-rata tertangkapnya kurisi (Nemipterus hexodon)

\section{Periode waktu tertangkap ikan timun}

Ikan timun memperoleh hasil tangkapan sama banyak pada pukul 06.00-12.00 dan 12.00-18.00 WIB dengan jumlah 7 ekor dan nilai rata-rata \pm SE 0,4 ekor $\pm 0,152$ pada umpan cumi-cumi. Umpan ikan juwi memiliki tangkapan terbanyak pada pukul 06.00-12.00 WIB dengan jumlah 1 ekor dan nilai rata-rata \pm SE 0,05 ekor $\pm 0,05$ dan umpan wak-wak memiliki tangkapan terbanyak pada pukul 02.00-18.00 WIB dengan jumlah 10 ekor dan nilai rata-rata \pm SE 0,5 ekor $\pm 0,17$ (Gambar 13). 


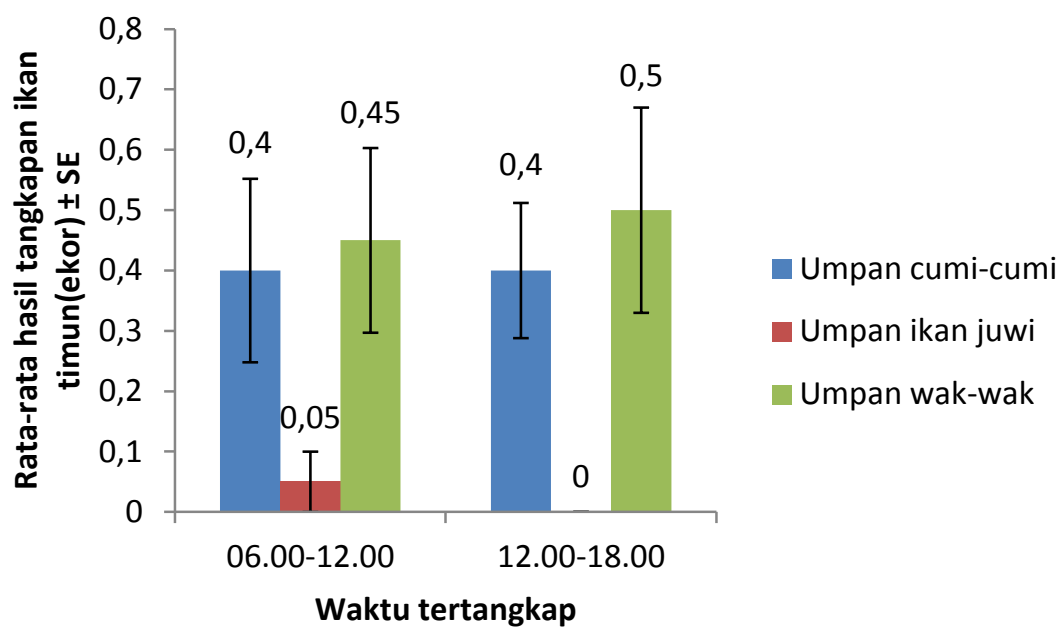

Gambar 13 Periode rata-rata tertangkapnya ikan timun (Lutjanus carponotatus)

\section{SIMPULAN DAN SARAN}

\section{Simpulan}

1. Komposisi hasil tangkapan pancing ulur terdiri dari 11 jenis ikan yaitu ikan kuwe kuning (Caranx bartholomei) dengan jumlah hasil tangkapan 68 ekor, kuwe rambe (Alectis ciliaris) 18 ekor, Barakuda (Sphyraena baraccuda) 29 ekor, Kunyit (Lutjanus vita) 39 ekor, timun (Lutjanus carponotatus) 31 ekor, lencam (Lethrinus lentjan) 19 ekor, kurisi (Nemipterus hexodon) 36 ekor, kerapu sunu (Plectropomus areolatus) 7 ekor, kerapu ekor gelap (Epinephelus bleekeri) 12 ekor, ungar (Lutjanus johnii) 6 ekor, dan kakap merah (Lutjanus campechanus) 7 ekor.

2. Umpan cumi-cumi, ikan juwi dan wak-wak ketiganya memberikan pengaruh nyata terhadap hasil tangkapan.

3. Waktu yang paling baik untuk menangkap ikan kuwe kuning, ikan kunyit dan ikan kurisi yaitu pada pukul 06.00-12.00 WIB, sedangkan untuk ikan timun yaitu pada waktu 12.00-18.00 WIB.

\section{Saran}

Perlu adanya penelitian lanjutan terhadap umpan alternatif cacing wak-wak (Xenosiphon sp.) pada pancing ulur yang dibandingkan dengan umpan cumi-cumi dan ikan juwi namun dioperasikan pada malam hari di Kecamatan Manggar Pulau Belitung.

\section{DAFTAR PUSTAKA}

Carton AG, Montgomery JC. 2003. Evidence of Rheotactic Component in The Odour Search Behavior of Freshwater Eels. Journal of Fish Biology (62): 501-516.

Cutler, E.B, 1994. The Sipuncula: their systematics, biology, and evolution. Cornell University Press. New York. 453 pp.

Dinas Kelautan dan Perikanan. 2013. Statistik Produksi Perikanan Tangkap Bangka Belitung. Belitung Timur (ID). Belitung.
Gunarso, W. 1985. Suatu Pengantar Tentang Tingkah Laku Ikan Terutama Dalam Hubungannya Dengan Alat, Metode Dan Taktik Penangkapan. Fakultas Perikanan IPB.Bogor. 142 hal.

Hendrotomo M. 1989. Studi Analisis Tangkapan dengan Mneggunakan Umpan yang Berbeda pada Rawai Cucut (Hiu) Permukaan Pelabuhan Ratu [Skripsi]. Bogor. Fakultas Perikanan dan Ilmu Kelautan. Institut Pertanian Bogor. Bogor.

Kozloff, E. N., 1990. Invertebrates, Sounders College Publishing.

Liang XF, Liu JK, Huang BY. 1998. The Role of Sense Organs in The Feeding Behavior of Chinese Pearch. Journal of Fish Biology(52): 1058-1067.

Muammar. 2013. Analisis Hasil Tangkapan Ikan Dengan Mneggunakan Rawai Pada Daerah Penangkapan Yang telah Dipasangi Rumah Ikan dan Tanpa Rumah Ikan di perairan Bengkalis, Riau. Fakultas Perikanan dan Ilmu Kelautan Universitas Riau. Pekanbaru.

Silahooy F. 2008. Analisa Kandungan Asam Amino dan Asam Lemak Cacing Laut [Skripsi]. Fakultas Matematika dan Ilmu Pengetahuan Alam. Universitas Patimura.

Walpole, R.E. 1995. Pengantar Statistika. PT. Gramedia Pustaka Utama: Jakarta. 515 halaman. 